\section{Ground-penetrating Radar to Detect and Quantify Residual Root Fragments Following Peach Orchard Clearing}

\author{
K.D. $\operatorname{Cox}^{1}$, H. Scherm ${ }^{1,3}$, and N. Serman ${ }^{2}$
}

AdDitional Index words. Prunus persica, georadar, replant disease, inoculum potential, Armillaria

Summary. Consecutive replanting of peach (Prunus persica) trees on the same orchard site can result in various replant problems and diseases, including armillaria root disease (Armillaria spp.), which develops upon contact between the roots of newly planted trees and infested residual root pieces in the soil. There is little information regarding the quantity of roots remaining in stone fruit orchards following tree removal and land clearing. We investigated the utility of ground-penetrating radar (GPR) to characterize reflector signals from peach root fragments in a controlled burial experiment and to quantify the amount of residual roots remaining after typical commercial orchard clearing. In the former experiment, roots ranging from 2.5 to $8.2 \mathrm{~cm}$ in diameter and buried at depths of 11 to $114 \mathrm{~cm}$ produced characteristic parabolic reflector signals in radar profiles. Image analysis of high-amplitude reflector area indicated significant linear relationships between signal strength (mean pixel intensity) and root diameter $(r=-0.517 ; P=0.0097 ; n=24)$ or the combined effects of root diameter and burial depth, expressed though a depth $\times$ diameter term $(r=-0.630 ; P=$ $0.0010 ; n=24)$. In a peach orchard in which trees and roots had been removed following typical commercial practice (i.e., trees were pushed over, burned, and tree rows subsoiled), a GPR survey of six $4 \times 8-\mathrm{m}$ plots revealed that the majority of reflector signals indicative of root fragments were located in the upper 30 to $40 \mathrm{~cm}$ of soil. Based on ground-truth excavation of selected sites within plots, reflectors showing a strong parabolic curvature in the radar profiles corresponded to residual root fragments with $100 \%$ accuracy, whereas those displaying a high amplitude area represented roots in $\mathbf{8 6 . 1 \%}$ of the cases. By contrast, reflectors with both poor curvature and low amplitude yielded roots for less than $10 \%$ of the excavated sites, whereas randomly selected sites lacking reflector signals were devoid of any roots or other subsurface objects. A high level of variability in the number of residual roots was inferred from the radar profiles of the six plots, indicating an aggregated distribution of root fragments throughout the field. The data further indicated that at least one residual root fragment would be present per cubic meter of soil, and that many of these fragments have diameters corresponding to good to excellent inoculum potential for armillaria root disease. Further GPR surveys involving different levels of land clearing, combined with long-term monitoring of armillaria root disease incidence in replanted trees, will be necessary to ascertain the disease threat posed by the levels of residual root biomass observed in this study.

$\mathrm{P}$ each orchards are commonly replanted when orchard profitability begins to decline, which may be as early as 4 to 6 years after

\footnotetext{
Departments of ${ }^{1}$ Plant Pathology and ${ }^{2}$ Geology, University of Georgia, Athens, GA 30602

${ }^{3}$ To whom correspondence should be addressed: E-mail address: scherm@uga.edu

Acknowledgments: We thank Alex Csinos (University of Georgia, Tifton), the staff at the Bowen Farm, and Frank Funderburk (Peach County Cooperative Extension Service) for assistance in locating and preparing the experimental sites; Tom Beckman (USDA-ARS Southeastern Fruit and Tree Nut Research Laboratory) for providing peach root material; and Clint Truman and Ricky Fletcher (USDA-ARS Southeast Watershed Research Laboratory) for useful discussions and help with preliminary GPR runs.
}

initial establishment (Steiner and Lockwood, 2005). Consecutive replanting on the same orchard site can result in various replant problems and diseases as soilborne pathogen populations increase (Fehrmann, 1988). One such replant disease is armillaria root disease, which is caused by several species of the basidiomycete Armillaria. Armillaria species occur worldwide, and they attack a wide variety of hardwood and softwood plants, including many stone fruit species (Cooley, 1943; Raabe, 1962; Shaw and Kile, 1991). The species $A$. tabescens and $A$. mellea can cause extensive tree mortality in peach orchards in the southeastern U.S. (Miller, 1994; Rhoads, 1954; Savage et al., 1953), a problem that is becoming more prevalent as producers are forced to plant into forest lands or old orchard sites with endemic populations of these fungi. Armillaria populations are capable of surviving for decades on infested root pieces that remain in the soil after tree removal (Reaves et al., 1993; Roth et al., 2000), and contact between growing roots of replanted trees and infested residual root pieces in the soil is thought to initiate the disease (Rishbeth, 1964; Savage et al., 1953). Residual roots with diameters as small as $0.7 \mathrm{~cm}$ can support survival of Armillaria, whereas those of larger diameters are more important for establishing infection based on their greater inoculum potential (Bliss, 1951; Chandler and Daniel, 1982; Patton and Riker, 1959). Thus, thorough removal of large root fragments after orchard clearing is an important strategy for reducing the disease in replant situations (Cox et al., 2005; Shaw and Kile, 1991; Steiner, 1976).

There is little information regarding the quantity of residual roots remaining in peach orchards after commercial tree removal and land clearing practices, or the extent to which these root fragments are of a size that would support survival of Armillaria. Various excavation techniques, ranging from manual digging to pressurized air or water excavation, have been employed to study the root systems of trees in situ before or after tree removal (Bohm, 1979; Carlson et al., 1988; Jenik, 1978; Nicoll and Armstrong, 1998; Pareek et al., 1993; Rizzo and Gross, 2000; Stokes et al.,

\begin{tabular}{lllc}
\hline $\begin{array}{l}\text { Units } \\
\text { To convert U.S. to SI, } \\
\text { multiply by }\end{array}$ & U.S. unit & SI unit & $\begin{array}{l}\text { To convert SI to U.S., } \\
\text { multiply by }\end{array}$ \\
\hline 0.3048 & $\mathrm{ft}$ & $\mathrm{m}$ & 3.2808 \\
0.0283 & $\mathrm{ft}^{3}$ & $\mathrm{~m}^{3}$ & 35.3147 \\
2.5400 & inch(es) & $\mathrm{cm}^{2}$ & 0.3937 \\
6.4516 & inch & $\mathrm{cm}^{2}$ & 0.1550 \\
16.0185 & $\mathrm{lb} / \mathrm{ft}^{3}$ & $\mathrm{~kg} \cdot \mathrm{m}^{-3}$ & 0.0624 \\
28.3495 & $\mathrm{oz}$ & $\mathrm{g}$ & 0.0353 \\
1001.1539 & $\mathrm{oz} / \mathrm{ft}^{3}$ & $\mathrm{~g} \cdot \mathrm{m}^{-3}$ & 0.0010
\end{tabular}


2002), but these techniques are often too invasive and/or too laborious to survey large areas. Similarly, indirect techniques, such as measuring sap flow or the use of radioactive tracers to study root systems (Cremák and Kucera, 1990; Cremák et al., 1980; Woods, 1969), are uninformative of root structure and unsuitable for quantifying residual root fragments. By contrast, GPR is a nondestructive geophysical technique that can both detect tree roots and characterize their distribution. GPR is a pulse radar system in which pulses of electromagnetic energy are transmitted into the soil from an antenna. Electromagnetic waves are partially reflected back to the antenna off of subsurface features of varying electromagnetic properties, and these are subsequently converted into a digitized image of waveforms (Butnor et al., 2001; Daniels, 1996; Morey, 1974; Ulriksen, 1982). Due to the change in travel time of the electromagnetic waves as the antenna passes over them (Barker and Doolittle, 1982), roots and other discrete subsurface objects produce hyperbolic reflector signals in the radar profile, and the shape and intensity of these characteristic reflectors can be used to identify roots (Butnor et al., 2001). GPR has been applied successfully to detect, characterize, and map tree root systems in the subsurface of forest stands and urban environments under concrete and asphalt (Butnor et al., 2001; Cremák et al., 2000; Hruska et al., 1999; Stokes et al., 2002). However, the technique has not been used previously to detect and quantify residual root pieces beneath the soil surface following orchard clearing.

The purpose of this study was to provide proof of concept for GPR detection of residual peach root fragments in the soil following orchard clearing. Specifically, we wished to 1 ) characterize reflector signals from root pieces in a controlled burial experiment, and 2) quantify the amount of residual roots remaining after orchard clearing typical of commercial practice. Information derived from this study could shed light on the potential amount of Armillaria inoculum remaining in peach orchards after commercial tree removal and replant practices. The study could also help clarify the extent to which residual root fragments are of a size favoring survival of Armillaria.

Table 1. Aspects of the controlled burial experiment to characterize reflector signals of peach root fragments or polyvinyl chloride (PVC) pipe standards by ground-penetrating radar

\begin{tabular}{|c|c|c|c|c|c|}
\hline \multicolumn{4}{|c|}{ Peach root fragments } & \multicolumn{2}{|c|}{ PVC pipes ${ }^{z}$} \\
\hline Diam & Depth $^{y}$ & Length & Orientation $^{\mathrm{x}}$ & Diam & Depth \\
\hline$-\cdots$ & $\mathrm{cm}^{\mathrm{w}}--$ & . & & ------ & 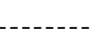 \\
\hline 3.1 & 44 & 60 & Horizontal & 3.1 & 63 \\
\hline 3.2 & 27,18 & 51 & Upward & 4.0 & 82 \\
\hline 2.5 & 41,11 & 90 & Upward & 6.0 & 45 \\
\hline 2.7 & 28 & 62 & Horizontal & 3.1 & 35 \\
\hline 6.1 & 58,52 & 60 & Upward & 6.0 & 23 \\
\hline 3.5 & 78,70 & 52 & Upward & 6.0 & 57 \\
\hline 5.2 & 52,77 & 70 & Downward & 4.0 & 25 \\
\hline 8.2 & 86 & 70 & Horizontal & 6.0 & 86 \\
\hline 2.5 & 38,52 & 51 & Downward & 4.0 & 44 \\
\hline 7.3 & 64 & 60 & Horizontal & 3.1 & 82 \\
\hline 2.5 & 85,113 & 55 & Downward & 4.1 & 66 \\
\hline 3.3 & 88,114 & 70 & Downward & 3.1 & 29 \\
\hline
\end{tabular}

${ }^{2}$ All pipes were $70 \mathrm{~cm}(27.6$ inches $)$ long and inserted into the trench face horizontally.

yThe first number corresponds to the insertion depth of the root fragment into the trench face. The second measurement represents the depth at the endpoint for roots oriented "upward" or "downward."

"Orientations "upward" and "downward" indicate insertions at an angle up or down into the face of the trench. w $1 \mathrm{~cm}=0.3937$ inch.

\section{Materials and methods}

\section{CONTROLLED BURIAL EXPERIMENT.} The purpose of this experiment was to characterize the GPR reflector signals of peach roots in nearly ideal conditions. It was carried out on a fallow area at the Bowen Farm near Tifton, Ga., on a Pelham loamy sand $(92.5 \%$ sand, $7.2 \%$ silt, $0.5 \%$ clay). A trench 20 $\mathrm{m}$ long, $1.5 \mathrm{~m}$ wide, and $1.2 \mathrm{~m}$ deep was dug with a backhoe, and peach root segments or polyvinyl chloride (PVC) pipes (used as standards) were inserted into the trench face at different depths and in different orientations as described below. The root segments $(2.5$ to $8.2 \mathrm{~cm}$ in diameter and at least $50 \mathrm{~cm}$ long) had been collected at the USDA-ARS Southeastern Fruit and Tree Nut Research Laboratory, Byron, Ga., from mature peach trees on 'Lovell' rootstock that had been pushed over using a front-end loader. Roots were stored in a freezer between collection and use to avoid desiccation of the tissue. The PVC pipes were 3.1 to $6.0 \mathrm{~cm}$ in diameter and cut to $70-\mathrm{cm}$ length to ensure complete coverage across the signal footprint when the antenna was pulled across the soil surface next to the trench (see description below).

The controlled burial experiment involved three factors: root diameter, depth of burial, and orientation of the root segment relative to the ground plane (Table 1). Root diameters were within a range most relevant for Armil- laria survival (Bliss, 1951; Chandler and Daniel, 1982; Glenn and Welker, $1993)$. With the aid of a rubber mallet, root segments and PVC pipes were pushed into the trench face at four depth classes (about 25, 45, 60, and 80 $\mathrm{cm})$. These depths were chosen to encompass the range of depths previously reported for stone fruit tree rooting (Glenn and Welker, 1993; Godara et al., 2000). The direction of insertion was either horizontal, angled upward, or angled downward to simulate varying root orientations (Table 1 ). There was a total of 12 root segments and 12 PVC pipes, with individual objects spaced about $1 \mathrm{~m}$ apart to avoid overlap of reflector signals. Most insertions were made in the eastern face of the trench as the deposition of excavated soil on the western trench shelf allowed only surveying up to $6 \mathrm{~m}$ on that side.

Two days after insertion of the objects into the trench face, both shelves of the trench were surveyed using a hand-pulled, ground-coupled 900-MHz antenna (3101D; Geophysical Survey Systems, Inc., North Salem, N.H.), each in a series of five transects $25 \mathrm{~cm}$ apart starting at the edge of the trench face. This was done to ensure complete coverage of the roots and pipes. The antenna was calibrated for gain and soil dielectric constant estimated on site (range gain settings $=20,49,49$, and $65 \mathrm{~dB}$; dielectric constant $=5$ ). Radar profiles were collected in 8-bit files with a range of 30 nanoseconds (ns). The radar 


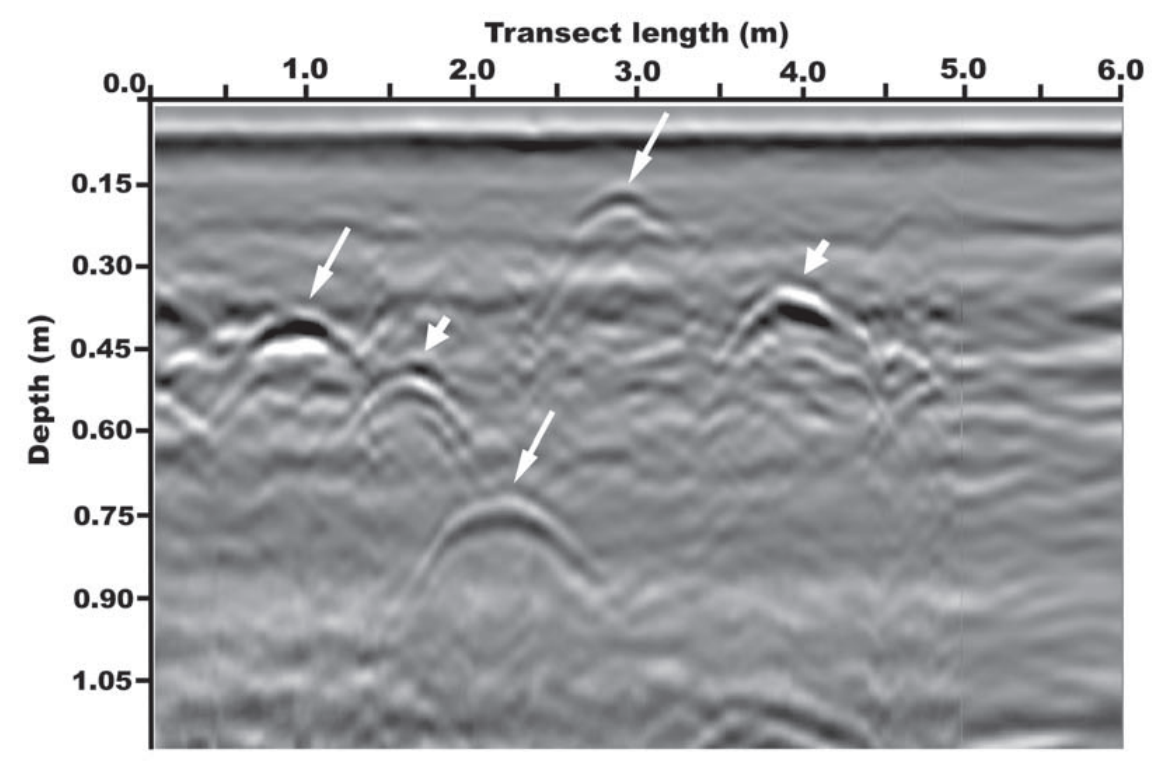

Fig. 1. Representative radar profile from the western trench face in the controlled burial experiment to characterize reflector signals of peach root fragments or polyvinyl chloride (PVC) pipe standards by ground-penetrating radar. Parabolic shapes indicated by long and short arrows correspond to roots and pipes, respectively $(1 \mathrm{~m}=3.2808 \mathrm{ft})$.

profiles were viewed in color table 17 (grayscale) with linear color transform, and processing was limited to standard marker editing and horizontal scaling (distance normalization) using RADAN (version 3.1 for Windows NT; Geophysical Survey Systems). An example profile from the western trench face is shown in Fig. 1. Further processing with RADAN using standard Finite Impulse Response (FIR) filters to remove background noise and Kirchoff migration to collapse hyperbolic diffractions was performed to determine if clarity of reflector signals could be improved.

Following color table customization and horizontal scaling, the qualitative radar profiles were converted to numerical data using Scion Image software (Scion Corp., Frederick, Md.) to quantify reflector signal strength. The high-amplitude area of each reflector was selected and analyzed for mean intensity on an 8-bit scale, giving intensity values from 0 to 255 , with high- and low-amplitude areas appearing lighter (lower values) and darker (higher values), respectively. The resulting mean pixel intensity for each reflector was used as a measure of relative signal strength in subsequent linear regression analyses to investigate the dependence of pixel intensity on depth and diameter of roots and pipes (SigmaPlot version 7.0; SPSS, Inc., Chicago).
GPR SURVEY OF PEACH ROOT FRAGMENTS FOLLOWING ORCHARD CLEARING IN COMMERCIAL CONDITIONS. The experiment was carried out in a commercial peach orchard near Byron, Ga. The soil was a Faceville fine sandy loam $(85.4 \%$ sand, $10.3 \%$ silt, $4.3 \%$ clay) with a hardpan containing higher percentages of clay and silt at a depth of 30 to $40 \mathrm{~cm}$. The orchard had been cleared by the producer in July 2003, which involved pushing the trees over, piling and burning them, and subsoiling the tree rows to the depth of the hardpan. Apart from mechanical weed control with a harrow, the cleared area lay fallow throughout the subsequent fall and winter. In Jan. 2004 , just prior to replanting, six $4 \times$ 8 -m plots were established randomly across the fallow field. Multiple small plots were used to increase the likelihood of including areas with varying residual root levels, and the size of plots was chosen to encompass the area typically allocated to an individual tree under standard spacing practices. Each plot was surveyed with a hand-pulled, ground-coupled $900-\mathrm{MHz}$ antenna (3101D; Geophysical Survey Systems) in a series of nine 8 -m transects $(y$-direction) with $50 \mathrm{~cm}$ spacing between transects (Fig. 2). Each plot was also surveyed in the $x$-direction to produce 4 -m transects, but only the $y$-transects were used subsequently for analysis as

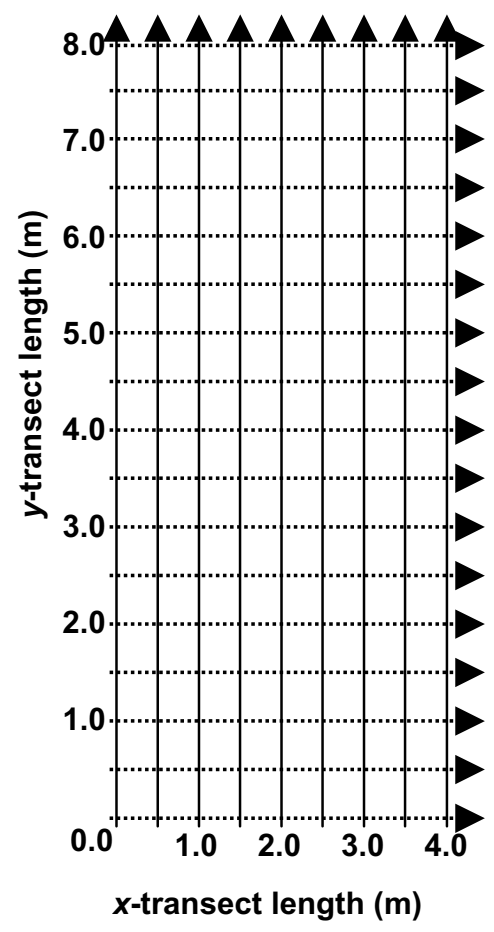

Fig. 2. Schematic representation of one of the plots surveyed to detect and quantify residual peach root fragments by ground-penetrating radar following orchard clearing. Individual survey transects, indicated by arrows, were spaced $50 \mathrm{~cm}$ (19.7 inches) apart. Each plot was surveyed in two directions as indicated by the directionality of transects $(1 \mathrm{~m}=3.2808 \mathrm{ft})$.

the reflectors in the short $x$-direction profiles were more difficult to distinguish. The antenna was calibrated on site (range gain settings $=21,47,51$, and $63 \mathrm{~dB}$; dielectric constant $=20$ ), and radar profiles (range $30 \mathrm{~ns}$ ) were collected and processed as described above for the controlled burial experiment.

The individual radar profiles were examined for characteristic parabolic reflector signals indicative of roots, the position of these reflectors was marked, and the visual reflector characteristics "parabolic curvature" and "amplitude" (indicating signal attenuation) were recorded. Reflectors potentially corresponding to roots were subjectively categorized into four classes: 1) having contrasting bands of high amplitude and a well-defined parabolic shape; 2 ) having poor amplitude contrast, but a well-defined parabolic shape; 3 ) having contrasting bands of high amplitude, but only slight curvature; and 4) having poor amplitude contrast and slight curvature (Fig. 3). This simplified visual 


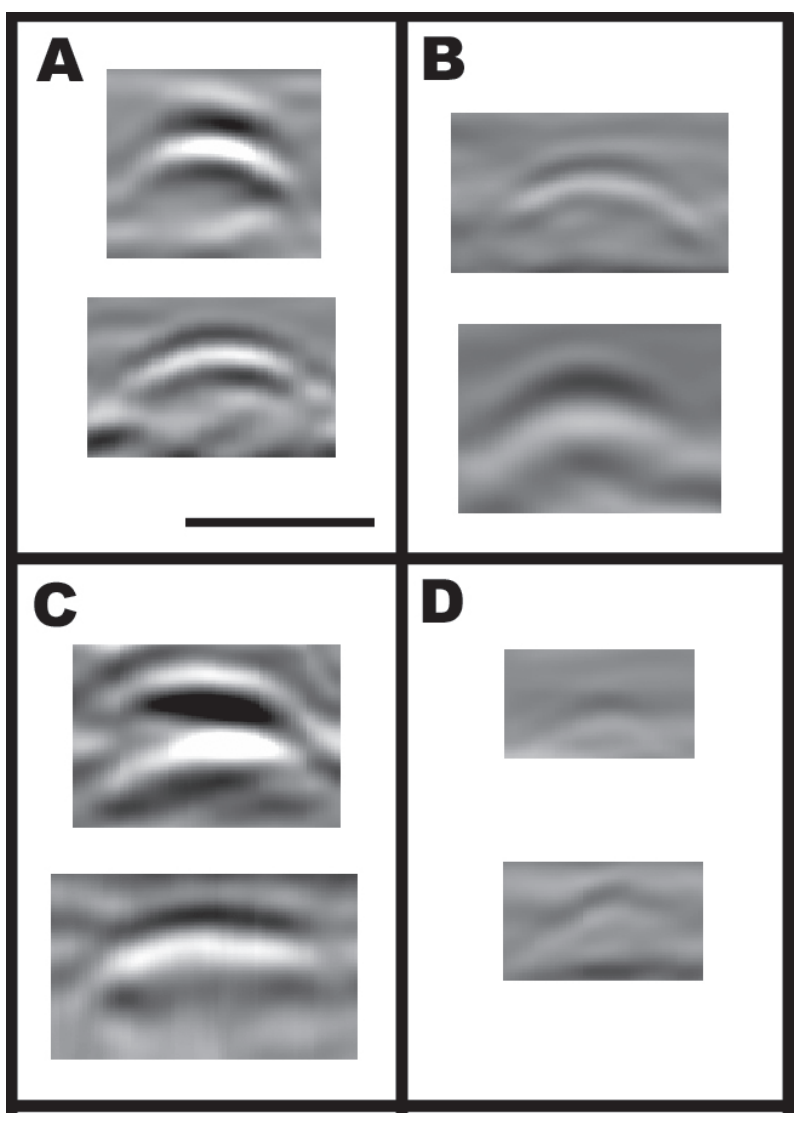

Fig. 3. Ground-penetrating radar reflector signals representing different combinations of signal characteristics in a cleared peach orchard. Signals potentially corresponding to root fragments were categorized into four classes: A) having contrasting bands of high amplitude and a well-defined parabolic shape; $\mathrm{B}$ ) having poor amplitude contrast, but a well-defined parabolic shape; C) having contrasting bands of high amplitude, but only slight curvature; and D) having poor amplitude contrast and slight curvature. Scale bar $=50 \mathrm{~cm}$ (19.7 inches).

categorization scheme was used to facilitate ease of interpretation by nonspecialists and to determine the extent to which such a system would allow for accurate root identification.

Across all six plots, 100 validation sites (each of about 25 -cm radius) were selected for ground-truth excavation to a depth of about $60 \mathrm{~cm}$, with $75 \mathrm{se}$ lected from areas containing potential root signals (i.e., having characteristics of reflector classes 1 through 4 above) and 25 selected from areas lacking any reflectors in the radar profiles. The number of excavation sites that yielded root fragments was counted for each of the four reflector classes and used as a measure of accuracy for predicting the presence of root fragments based on the characteristics of that reflector class.

For each reflector class, mean root characteristics (diameter, length, and dry weight) were calculated across all roots excavated as part of that class.
Then, each radar profile was inspected for the total number of reflectors in each class, and the density of root fragments per cubic meter of soil was calculated by tallying the numbers of reflectors from each of the reflector classes with the highest ground-truth accuracy [i.e., classes 1 through 3 (see results)] and dividing this number by the volume of soil $\left(8 \times 4 \times 0.6 \mathrm{~m}^{3}\right)$ considered in the survey of each plot. Similarly, the biomass contribution of each reflector class was calculated by multiplying the mean dry weight of roots in that class by the number of reflectors belonging to the signal class. Root biomass was then estimated for each plot by summing the biomass contributions of each class within the plot and dividing by the volume of soil considered in the survey.

\section{Results and discussion}

CONTROLled BURIAL EXPERIMENT. With minimal downstream signal processing, all root segments and PVC pipes produced discernible parabolic reflector signals in the radar profiles (Fig. 1). Additional processing with FIR filters and Kirchoff migration to remove background noise and collapse hyperbolic diffractions, respectively, did not improve clarity or position of reflector signals further (data not shown). The reflectors varied in the clarity of shape and in signal strength, but there were no apparent differences in signals between roots and pipes of similar diameter, burial depth, and orientation (Fig. 1). The reflector shapes and intensities produced by the roots in our study were similar to those described in previous reports (Barker and Doolittle, 1982; Butnor et al., 2001; Hruska et al., 1999; Truman et al., 1988).

With the GPR system used in this study we were able to detect roots of all diameters $(2.5$ to $8.2 \mathrm{~cm})$ and burial depths (11 to $114 \mathrm{~cm}$ ) (Table 1). By comparison, a $400-\mathrm{MHz}$ antenna used in a previous GPR survey of root systems of sessile oak (Quercus petraea) in situ (Hruska et al., 1999) had a somewhat lower resolution ( 3 to $4 \mathrm{~cm}$ root diameter) but greater depth of penetration (up to $2 \mathrm{~m}$ ) compared with the $900-\mathrm{MHz}$ antenna used here. Moreover, the presence of multiple, overlapping roots in the latter study further compromised the potential to resolve roots of diameters less than 3 $\mathrm{cm}$ accurately. However, Butnor et al. (2001) were able to clearly distinguish loblolly pine (Pinus taeda) roots as small as $0.5 \mathrm{~cm}$ in diameter using a $1.5-\mathrm{GHz}$ antenna and larger roots ( $>3.7 \mathrm{~cm}$ diameter) using a $400-\mathrm{MHz}$ antenna in situ. The resolution of the 1.5-GHz antenna was sufficient to distinguish small-diameter roots at depths of 35 to $60 \mathrm{~cm}$ depending on soil type, whereas the $400-\mathrm{MHz}$ antenna allowed for detection of larger roots at depths greater than $1 \mathrm{~m}$.

Relative to assessing potential $A r$ millaria inoculum on peach roots, root pieces less than $2.5 \mathrm{~cm}$ in diameter are less conducive to survival and weaker in inoculum potential than fragments with larger diameters (Bliss, 1951; Chandler and Daniel, 1982; Garrett, 1956, 1957). Moreover, most coarse peach roots are found in the top 50 $\mathrm{cm}$ of soil (Glenn and Welker, 1993; Godara et al., 2000), and only few roots are observed below $60 \mathrm{~cm}$ in southeastern peach orchards (personal 

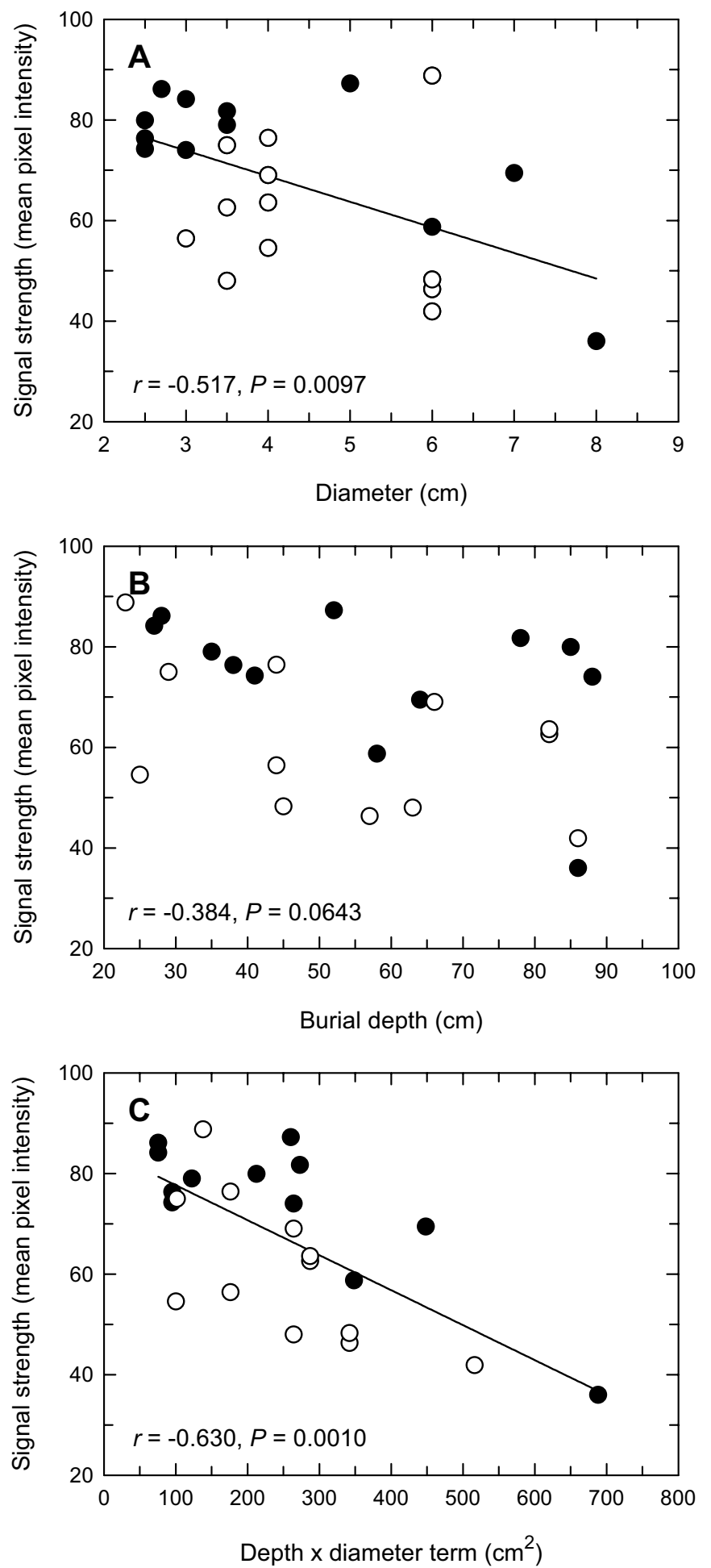

Fig. 4. Relationships between signal strength and root characteristics derived from the controlled burial experiment to characterize reflector signals of peach root fragments $(\odot)$ or polyvinyl chloride (PVC) pipe standards $(\bigcirc)$ by groundpenetrating radar. Signal strength is expressed as the mean pixel intensity (range 0 to 255) for the high-amplitude area of the reflector signals, with lower values indicative of stronger intensity. The depth $\times$ diameter term in $\mathrm{C}$ corresponds to the product of burial depth and root diameter. Lines in A and $\mathrm{C}$ indicate significant $(P \leq 0.05)$ linear regression relationships for the pooled root-pipe data; the regression lines were fitted to pooled data after an analysis of covariance (Littell et al., 1991) showed that slopes for pipes and roots were not significantly different $(P=0.668$ and 0.641 for diameter and depth $\times$ diameter, respectively; $1 \mathrm{~cm}$ $\left.=0.3937 \mathrm{inch}, 1 \mathrm{~cm}^{2}=0.1550 \mathrm{inch}^{2}\right)$. observation). The use of a $900-\mathrm{MHz}$ antenna in our study therefore represented a sound compromise in terms of resolution, depth of penetration, and biological relevance of the resulting information.

Apart from merely detecting the presence of roots, we were able to explore relationships between reflector signal strength (indicated by reflector pixel intensity following image analysis) and depth and diameter of roots. We found a significant negative correlation between signal strength and the diameter of root and pipes $(r=-0.517 ; P=$ $0.0097 ; n=24$ ) (Fig. 4A), indicating that larger roots produced higheramplitude signals (which correspond to lower values of pixel intensity on the 0 to 255 scale). By contrast, the relationship between signal strength and burial depth was significant only at the $\alpha=0.10$ level $(r=-0.384 ; P=$ $0.0643 ; n=24$ ) (Fig. 4B). Interestingly, the combined effect of depth and diameter, accounted for through use of a depth $\times$ diameter term in the regression analysis, resulted in a stronger correlation with signal strength $(r=$ $-0.630 ; P=0.0010 ; n=24$ ) (Fig. $4 \mathrm{C}$ ). Butnor et al. (2001) explored similar relationships with root diameter and biomass using the high-amplitude area of cottonwood (Populus deltoides) and loblolly pine root reflectors in sandy soils. They reported significant correlations between pine root diameter and high-amplitude area at depths of 15 and $30 \mathrm{~cm}$. Interestingly, the strength of the relationship declined with increasing depth, and there was no significant association between cottonwood root diameter and high-amplitude area (Butnor et al., 2001). In the current study, we found that accounting for depth, through a combined depth-diameter term, better explained reflector signal strength.

GPR SURVEY OF PEACH ROOT FRAGMENTS FOLLOWING ORCHARD CLEARING IN COMMERCIAL CONDITIONS. All six plots contained radar profiles with reflector signals suggestive of root fragments. Most of these reflectors were located in the top 30 to 40 $\mathrm{cm}$ of soil (Table 2) above a hardpan in which few reflectors were present. Excavation at the 25 randomly selected validation sites which lacked reflector signals revealed no roots or other subsurface objects. Of the 75 reflectors selected for excavation and validation, 21 were classified into class 1 (high 
Table 2. Classification of ground-penetrating radar reflector signals and associated root fragment characteristics determined by independent ground-truth excavation in a peach orchard following orchard clearing according to commercial practice

\begin{tabular}{|c|c|c|c|c|c|c|c|c|c|}
\hline \multirow{3}{*}{$\begin{array}{l}\text { Reflector } \\
\text { class }^{z}\end{array}$} & \multicolumn{3}{|c|}{ Reflector characteristics ${ }^{\mathrm{z}}$} & \multirow[b]{3}{*}{$n_{1}{ }^{\mathrm{u}}$} & \multirow[b]{3}{*}{$n_{2}{ }^{\mathrm{t}}$} & \multirow{2}{*}{\multicolumn{4}{|c|}{ Root characteristics ${ }^{\mathrm{y}}$}} \\
\hline & \multirow{2}{*}{$\begin{array}{c}\text { High } \\
\text { amplitude }^{\mathrm{x}}\end{array}$} & \multirow{2}{*}{$\begin{array}{l}\text { Strong } \\
\text { parabolaw }^{\text {w }}\end{array}$} & \multirow{2}{*}{$\begin{array}{c}\text { Weak } \\
\text { parabola }^{\mathrm{v}}\end{array}$} & & & & & & \\
\hline & & & & & & Diam & Depth & Length & Dry wt \\
\hline 1 & + & + & - & 21 & 21 & 3.2 & 26.2 & 25.1 & 82.4 \\
\hline 2 & - & + & - & 6 & 6 & 2.2 & 28.3 & 22.8 & 51.7 \\
\hline 3 & + & - & + & 15 & 10 & 1.7 & 30.5 & 19.4 & 18.0 \\
\hline
\end{tabular}

${ }^{2}$ Reflector characteristics and corresponding classes are illustrated in Figure 3.

yased on means across all roots in the reflector class. $1 \mathrm{~cm}=0.3937 \mathrm{inch} ; \mathrm{g}=0.0353 \mathrm{oz}$.

xIndicated by the presence of strong contrasting bands of high amplitude in the signal.

"Possessing a well-defined parabolic shape.

"Faint in contrast or slight in curvature.

"Number of excavations in the reflector class.

tNumber of excavations that yielded root fragments.

amplitude and a well-defined parabolic shape), six into class 2 (low amplitude, but well-defined parabolic shape), 15 into class 3 (high amplitude, but only slight curvature) and 33 into class 4 (low amplitude with slight curvature) (Table 2). In classes 1 and 2 , which represented reflectors with well-defined parabolic shape, all validation sites yielded root fragments (Table 2 ). On average, these root fragments had the largest diameters and the greatest biomass of all roots recovered from validation sites. Whereas the majority (15 out of 25) of reflectors in class 3 corresponded to root fragments, very few in class 4 yielded any roots. These root fragments had the smallest diameters and the least biomass on average (Table 2). Overall, reflectors showing a strong parabolic curvature in the radar profiles corresponded to residual root fragments with $100 \%$ accuracy, whereas those displaying a high amplitude area represented roots in $86.1 \%$ of the cases. By contrast, reflectors with both poor curvature and low amplitude yielded roots for less than $10 \%$ of the excavated sites and most likely represented background noise. It is unlikely that these faint reflectors represent a significant proportion of the residual roots remaining in the soil after orchard clearing.

Based on the high level of accuracy for root fragment detection using reflector classes 1 through 3 , total root counts were obtained for each plot based on the number of reflectors corresponding to these three classes in the radar profiles (Table 3 ). Plots 2 through 5 had the highest numbers of reflectors in classes that consistently corresponded to root

Table 3. Predicted root density and biomass based on ground-penetrating radar reflector signal classes in a peach orchard following orchard clearing according to commercial practice.

\begin{tabular}{|c|c|c|c|c|c|}
\hline \multirow[b]{2}{*}{$\operatorname{Plot}^{\mathrm{y}}$} & \multicolumn{3}{|c|}{ No. of roots ${ }^{\mathrm{z}}$} & \multirow{2}{*}{$\begin{array}{c}\text { Predicted } \\
\text { root density } \\
\left(\text { roots } / \mathrm{m}^{3}\right)^{\mathrm{x}}\end{array}$} & \multirow{2}{*}{$\begin{array}{r}\text { Predicted } \\
\text { biomass } \\
\left(\mathrm{g} \cdot \mathrm{m}^{-3}\right)^{\mathrm{x}, \mathrm{w}} \\
\end{array}$} \\
\hline & $\begin{array}{l}\text { Reflector } \\
\text { class } 1 \\
\end{array}$ & $\begin{array}{c}\text { Reflector } \\
\text { class } 2\end{array}$ & $\begin{array}{c}\text { Reflector } \\
\text { class } 3\end{array}$ & & \\
\hline 1 & 1 & 0 & 3 & 0.31 & 16.6 \\
\hline 2 & 6 & 3 & 14 & 1.80 & 76.8 \\
\hline 3 & 3 & 6 & 5 & 1.09 & 59.9 \\
\hline 4 & 9 & 3 & 2 & 1.09 & 77.5 \\
\hline 5 & 7 & 3 & 6 & 2.03 & 67.8 \\
\hline 6 & 2 & 3 & 8 & 1.02 & 45.6 \\
\hline
\end{tabular}

${ }^{2}$ Indicates number of reflector signals possessing the characteristics of the classes defined in Table 2 and Fig. 3. yEach plot was $4 \times 8 \mathrm{~m}(13.1 \times 26.2 \mathrm{ft})$ in size.

${ }^{x} 1 \mathrm{root} / \mathrm{m}^{3}=0.0283 \mathrm{root} / \mathrm{ft}^{3} ; 1 \mathrm{~g} \cdot \mathrm{m}^{-3}=0.0010 \mathrm{oz} / \mathrm{ft}^{3}$.

wCalculated from number of roots per reflector class per plot and mean dry weight of excavated roots in each reflector class (Table 2).

fragments. These plots also had the highest predicted root density and biomass (Table 3). Variability in predicted root density among plots may be due to an aggregated distribution of root fragments throughout the field. This is consistent with commercially used orchard clearing practices whereby trees are pushed over with a bulldozer or front-end loader, which often causes trees to break off at the crown, leaving the majority of the roots in the soil. The subsequent tractor raking typical of the land-clearing process may fail to remove all of the remaining roots in tree rows, resulting in alternating higher and lower areas of residual root density. Although the planting pattern of the cleared orchard was not known when our survey plots were established, it is possible that plots 2 through 5 were located near or above the old tree rows, hence the higher root biomass in these plots.

Armillaria root disease is charac- terized by patchy distribution in both forests and orchards (Baumgartner and Rizzo, 2002; Kable, 1974; Steiner, 1976; van der Kamp, 1995). Indeed, it is common to observe patches of dead trees, killed by Armillaria, surrounded by apparently healthy trees. This pattern is thought to be due to clumping of residual root inoculum resulting from inefficient tree removal or landclearing, which allows for contact between roots of newly planted trees and infested residual root fragments from the previous planting (Baumgartner and Rizzo, 2002; Savage et al., 1953; Steiner, 1976). Baumgartner and Rizzo (2002) found that the patchy distribution of armillaria root disease in a commercial Vitis vinifera vineyard in California was due to a concomitant distribution of decaying residual roots below-ground. In the current study, the patchy residual root distribution among plots is consistent with the patchy incidence of armillaria root 
disease commonly observed in peach orchards in the southeastern U.S.

Following peach orchard removal, our study indicates the presence of numerous residual root fragments that may serve as potential inoculum for armillaria root disease. Patton and Riker (1959) demonstrated that pine root segments with diameters from 0.7 to $5 \mathrm{~cm}$ supported survival of Armillaria for 10 to 35 months; they also concluded that the size of inoculum was not important for fungal survival. However, other studies in peach and citrus (Citrusspp.) asserted that Armillaria root inoculum of larger diameters favors longer-term survival (Bliss, 1951; Chandler and Daniel, 1982). Furthermore, large-diameter $(\geq 1.75$ $\mathrm{cm}$ ) roots are thought to be more important for Armillaria infection as they have greater inoculum potential than those of smaller diameters. In experiments in which potato (Solanum tuberosum) tubers were colonized from root inoculum of different sizes, Garrett $(1956,1957)$ concluded that larger Armillaria inoculum provides greater energy for infection, and, conversely, the proportion of successful infections decreases with decreasing inoculum size. In the current study, numerous root fragments with diameters greater than $1.75 \mathrm{~cm}$ (a size that is both conducive to survival of Armillaria and provides a good to excellent inoculum potential sensu Garrett) were detected with GPR. Indeed reflector signal classes 1 to 3 represent root pieces with diameters greater than $1.7 \mathrm{~cm}$ on average and account for the majority of the roots detected in our survey (Table 2). With the exception of plot 1 , it was predicted that at least one residual root fragment would be present in every cubic meter of soil, and many of these fragments correspond to signal classes representing diameters with good inoculum potential (Tables 2 and 3 ).

In the GPR survey of the commercial replant orchard, the predicted residual root biomass per plot ranged from 16.6 to $77.5 \mathrm{~g} \cdot \mathrm{m}^{-3}$ of soil (Table 3 ); this could pose a substantial infection threat to newly planted trees, as only $4 \mathrm{~g}$ of root inoculum can provide enough inoculum potential for successful infection by Armillaria (Garrett, 1956). To address the practical relevance of residual root inoculum, Roth et al. (2000) conducted a 20-year study using different land-clearing strategies for Armillaria inoculum reduction in a ponderosa pine (Pinus ponderosa) stand. For the land-clearing treatment most akin to that used in peach production (trees pushed over and maximum root removal by machine), the authors reported a residual dry-weight root biomass of more than $14 \mathrm{~kg} \cdot \mathrm{m}^{-3}$ of soil, which is almost 20 times higher than the highest biomass inferred in our survey. The pine trees were both much taller (site index of $32 \mathrm{~m}$ at 100 years) and growing at a higher density (tree spacing $<1.9 \mathrm{~m}$ ) than is the case for trees in a peach orchard. Thus, the observed difference in the magnitude of residual root biomass between the two studies with similar land-clearing practices is likely due to differences in root biomass input between pine stands and peach orchards. Interestingly, Roth et al. (2000) reported that maximum root removal by machine offered no reduction in armillaria root disease incidence on replanted ponderosa pine trees in their study.

\section{Conclusions}

In sandy or loamy soils that lack interfering subsurface features such as rocks, GPR using a $900-\mathrm{MHz}$ antenna can detect and quantify peach root fragments of diameters relevant to the survival of replant pathogens such as Armillaria. The GPR reflector signals can be classified visually according to their parabolic curvature and intensity, rendering the approach accessible to non-specialists. GPR can be used to evaluate orchard clearing practices by examining the amount of residual roots remaining after site preparation. A survey of a commercial replant orchard revealed a relatively high density of residual roots within the typical rooting depth of peach trees, suggesting that pre-plant orchard clearing and root removal practices should be intensified. Further GPR surveys involving different levels of land clearing, combined with long-term monitoring of armillaria root disease incidence in replanted trees, would be necessary to ascertain the disease threat posed by the levels of residual root biomass remaining after site preparation.

\section{Literature cited}

Barker, D.B. and J.A. Doolittle. 1982. Ground-penetrating radar-An archeological tool. Cultural Resource Mgt. $15: 25-28$.
Baumgartner, K. and D.M. Rizzo. 2002. Spread of armillaria root disease in a California vineyard. Amer. J. Enol. Viticult. 53:197-203.

Bliss, D.E. 1951. Destruction of Armillaria mellea in citrus soil. Phytopathology 41:665-683.

Bohm, W. 1979. Methods of studying root systems. Springer-Verlag, Berlin.

Butnor, J.R., J.A. Doolittle, L. Kress, S. Cohen, and K.H. Johnsen. 2001. Use of ground penetrating radar to study tree roots in the southeastern United States. Tree Physiol. 21:1269-1278.

Carlson, W.C., C.A. Harrington, P. Farnum, and S.W. Hallgren. 1988. Effects of root severing treatments on loblolly pine. Can. J. For. Res. 18:1376-1385.

Chandler, W.A. and J.W. Daniel. 1982. Observations on long-term survival of Clitocybe tabescens and infection of peach trees. Univ. of Georgia, College of Agr., Griffin.

Cooley, J.S. 1943. Armillaria root rot of fruit trees in the eastern United States. Phytopathology 33:812-817.

Cox, K.D., H. Scherm, and T.G. Beckman. 2005. Armillaria root and crown rot, p. 162-166. In: D. Horton and D. Johnson (eds.). Southeastern Peach Grower's Handbook. GES Hdbk. No. 1, Univ. of Georgia, Athens.

Cremák, J., J. Hruska, M. Martinkova, and A. Prax. 2000. Urban tree root systems and their survival near houses analyzed using ground penetrating radar and sap flow techniques. Plant Soil 219:103-116.

Cremák, J., J. Huzulak, and M. Penka. 1980. Water potential and sap flow rate in adult trees with moist and dry soil as used for the assessment of root system depth. Biol. Plant. (Praha) 22:34-41.

Cremák, J. and J. Kucera. 1990. Water uptake in healthy and ill trees, under drought and hypoxia and non-invasive assessment of the effective size of root systems, $\mathrm{p}$. 185-195. In: H. Persson (ed.). Proc. COST 612 Wkshp.: Above and Below-ground Interactions in Forest Trees in Acidified Soils, Simlangsdalen, Sweden.

Daniels, D.J. 1996. Surface penetration radar. Inst. Elec. Eng., London.

Fehrmann, W. 1988. Replant disease and its importance for fruit production. Acta Hort. 233:17-20.

Garrett, S.D. 1956. Rhizomorph behaviour in Armillaria mellea (Vahl) Quél. II. Logistics of infection. Ann. Bot. 20:193-209.

Garrett, S.D. 1957. Effect of a soil microflora selected by carbon disulphide 
fumigation on the survival of Armillaria mellea in woody tissues. Can. J. Microbiol. 3:135-149.

Glenn, D.M. and W.V. Welker. 1993. Root development patterns in field grown peach trees. J. Amer. Soc. Hort. Sci. 118:362-365.

Godara, A., S. Chitkara, and D. Ahlawat. 2000. Root distribution pattern in peach cv. Sharbarti. Haryana J. Hort. Sci. 29:161-163.

Hruska, J., J. Cremák, and S. Sustek. 1999. Mapping tree root systems with ground penetrating radar. Tree Physiol. 19:125-130.

Jenik, J. 1978. Root systems of oak trees: Morphogenic and ecological aspects, p. 323-349. In: P.B. Tomilson and M.H. Zimmerman (eds.). Tropical trees as living systems. Cambridge Univ. Press, Cambridge, U.K.

Kable, P.F. 1974. Spread of Armillariella $s p$. in a peach orchard. Trans. Brit. Mycol. Soc. 62:89-98.

Littell, R.C., R.J. Freund, and P.C. Specter. 1991. SAS system for linear models, 3rd ed. SAS Inst., Cary, N.C.

Miller, R.W. 1994. Estimated peach tree losses from 1980 to 1992 in South Carolina, causes and economic impact, p. 121-127. In: Proc. 6th Stone Fruit Decline Wkshp., 26-28 Oct. 1992, Ft. Valley, Ga.

Morey, R.M. 1974. Continuous subsurface profiling by impulse radar. Proc. ASCE Eng. Foundation Conf. on Subsurface Exploration for Underground Exploration and Heavy Construction. Amer. Soc. Civil Eng., New York.

Nicoll, B.C. and A. Armstrong. 1998. Development of Prunus root systems in a city street: Pavement damage and root architecture. Arboricult. J. 22:259-270.
Pareek, O.P., A. Chandra, and A.K. Godara. 1993. Root systems in fruit crops: Part 2, p. 1031-1053. In: Advances in horticulture, Vol. 2. Malhorta Publ. House, New Delhi.

Patton, R.F. and A.J. Riker. 1959. Artificial inoculations of pine and spruce trees with Armillaria mellea. Phytopathology 49:615-622.

Raabe, R.D. 1962. Host list of the root rot fungus Armillaria mellea. Hilgardia $33: 25-88$.

Reaves, J.L., C.G.I. Shaw, and L.F. Roth. 1993. Infection of ponderosa pine trees by Armillaria ostoyae: Residual inoculum versus contagion. Northwest Sci. 67:156-162.

Rhoads, A.S. 1954. Clitocybe root rot found widespread and destructive in Georgia and South Carolina peach orchards. Plant Dis. Rep. 38:42-46.

Rishbeth, J. 1964. Stump infection by basidiospores of Armillaria mellea. Trans. Brit. Mycol. Soc. 47:460-465.

Rizzo, D.M. and R. Gross. 2000. Distribution of Armillaria on pear root systems and a comparison of root excavation techniques, p. 305-311. In: Stokes, A. (ed.). The supporting roots of trees and woody plants: Form function and physiology. Kluwer, Dordrecht, The Netherlands.

Roth, L.F., C.G. Shaw, and L. Rolph. 2000. Inoculum reduction measures to control armillaria root disease in a severely infested stand of ponderosa pine in south-central Washington: 20 year results. Western J. Appl. For. 15:92-100.

Savage, E.F., J.H.Weinberger, E.S. Luttrell, and A.S. Rhoads. 1953. Clitocybe root rot, a disease of economic importance in Georgia peach orchards. Plant Dis. Rep. 37:269-270.
Shaw, C.G. and G.A. Kile. 1991. Armillaria root disease. Agr. Hdbk. 691. USDA For. Serv., Washington, D.C.

Steiner, P.W. 1976. White root rot: A threat to the Missouri peach industry. Trans. Illinois State Hort. Soc. 110:24-28.

Steiner, P.W. and D.W. Lockwood. 2005. Determining potential for replant problems, p. 28-32. In: D. Horton and D. Johnson (eds.). Southeastern peach grower's handbook. GES Hdbk. No. 1, Univ. of Georgia, Athens.

Stokes, A., T. Fourcaud, J. Hruska, J. Cremák, N. Nadyezdhina, V. Nadyezhdin, and L. Praus. 2002. An evaluation of different methods to investigate root system architecture of urban trees in situ: I. Ground-penetrating radar. J. Arboricult. 28:2-10.

Truman, C.C., H.F. Perkins, L.E. Asmussen, and H.D. Allison, 1988. Some applications of ground penetrating radar in the southern coastal plains region of Georgia. Res. Bul. 362, Univ. of Georgia, Athens.

Ulriksen, C.P.F. 1982. Application of Impulse Radar to Civil Engineering. Ph.D. Thesis, Lund University of Technology, Lund, Sweden.

van der Kamp, B.J. 1995. The spatial distribution of armillaria root disease in an uneven-aged, spatially clumped douglas-fir stand. Can. J. For. Res. 25:1008-1016.

Woods, F.W. 1969. Root extension of forest trees: A method of investigation using radioactive tracers, p. 413-417. In: W.J. Whitington (ed.). Root growth. Butterworth, London. 